\title{
AL-IDARAH:
}

JURNAL PENGKAJIAN DAKWAH DAN MANAJEMEN

ISSN-E : 2654-4407 | ISSN-P : 2337-5035

http://jurnal.uinsu.ac.id/index.php/idarah/index

Vol. 9 No. 2 Juli-Desember 2021, hlm. 22-27

\section{Strategi Media Dakwah Kontemporer}

\author{
Erwan Efendi \\ Universitas Islam Negeri Sumatera Utara Medan, Medan, Indonesia \\ Email Korespondensi: Erwanefendi@,uinsu.ac.id
}

\begin{abstract}
ABSTRAK
Dakwah Islam adalah kewajiban yang harus dilakukan umat muslim, terutama oleh ulama dan dai. Kegiatan menyampaikan ajaran Islam kepada seseorang atau sekelompok orang supaya mereka memeluk Islam atau melaksanakan ajaran Islam demi mencapai kebahagiaan di dunia dan akhirat. Kegiatan dakwah Islam makin lama makin memiliki beragam tantangan yang tidak mudah, bahkan bisa dikatakan sangat berat. Tantangan berdakwah di era milenial berhadapan dengan pesatnya perkembangan teknologi. Dakwah harus menyesuaikan diri dengan perkembangan perangkat yang terus berkembang pesat. Salah satu strategi yang tepat dilaksanakan dalam menghadapi pola hidup modern dalam kaitannya dengan penggunaan media dakwah kontemporer adalah memperbanyak pengenalan tentang tatacara penggunaan media dakwah kepada seluruh media yang ada, mendorong pencipta aplikasi untuk mengarahkan ciptaanya dalam mempermudah mengakses materi dakwah di internet, mengarahkan pengguna internet untuk lebih banyak membuka aplikasi keagamaan dibandingkan dengan aplikasi lainnya, membuka lebih luas untuk mempelajari pembuatan aplikasi yang bernuansa agama dibanding dengan aplikasi permainan.
\end{abstract}

Kata Kunci: Strategi; Media; Dakwah Kontemporer. 


\section{AL-IDARAH, Volume 9, No.2, 202123}

\section{PENDAHULUAN}

Dakwah pada era milenial benar-benar harus memanfaatkan media, utamanya media-media baru. Perkembangan teknologi komunikasi telah mengubah cara orang berkomunikasi. Saat ini, hampir setiap orang menggunakan internet dalam mengirim, mencari, dan membaca informasi. Dalam berinteraksi pun kebanyakan melalui media sosial dibanding komunikasi secara langsung. Hal ini sangat dimungkinkan terjadi setidaknya dipengaruhi beberapa faktor, antara lain pesatnya perkembangan teknologi informasi dan komunikasi, juga kecenderungan masyarakat milenial yang sangat bergantung pada media.

Kaitannya dengan dakwah, peran media sangat strategis dalam upaya penyampaian pesan dakwah. Media mampu menembus batasbatas ruang dan waktu. Artinya, meski dengan jarak jauh komunikasi memungkinkan dilakukan. Tidak hanya itu, media juga menawarkan kecepatan waktu dalam menyediakan beragam informasi. Media saat ini tumbuh kian pesat. Dulu, media elektronik seperti televisi dan radio menjadi pilihan favorit dalam mencari informasi. Keunggulannya adalah mampu mengirim pesan suara dan gambar (visual). Saat ini realita itu mulai bergeser. Publik tidak lagi berpusat pada media elektronik sebagai sumber informasi. Justru, kegandrungannya saat ini beralih ke new media (internet). Perkembangan media baru sebenarnya merujuk pada perubahan dalam proses produksi media, distribusi, dan penggunaan.

Fenomena lain yang muncul adalah adanya kendala dihadapi oleh para penyeru dakwah adalah dewasa ini sedang berhadapan dengan manusia yang memiliki multi budaya, beraneka ragam suku, pekerjaan dan profesi yang serba professional dan bahkan menghadapi manusia-manusia kontemporer dan mutakhir. Isu-isu kontemporer mulai meramba kehidupan manusia, baik di perkotaan maupun di pedesaan sudah memasuki seluruh sendi-sendi kehidupannya tak terkecuali umat Islam.

Pola hidup modern, banyak manusia terjebak pada sentuhan-sentuhan teknologi yang cenderung menggeser kepercayaan kepada Tuhan dan beralih pada pendewaan teknologi yang menyebabkan lemahnya iman. Syed Muhammad Naquib al-Attas menyebutkan bahwa telah banyak tantangan yang muncul di tengah-tengah kekeliruan manusia sepanjang sejarah, tetapi barangkali tidak ada yang lebih serius dan lebih merusak terhadap manusia daripada tantangan yang dibawa oleh peradaban barat. Peradaban tersebut terkait dengan pola hidup masyarakat dalam bentuk makanan, hiburan, pakaian dan keyakinan. Fenomena ini telah merambah pada seluruh lapisan 
masyarakat di Indonesia. Pola hidup dan pola pemikiran seperti tersebut berpengaruh besar pada keberadaan aqidah dan prilaku seseorang, terutama yang terkait dengan ajaran agama Islam.

Perlu optimalisasi komunikasi dakwah melalui pemanfaatan media baru (new media), utamanya media sosial, mengingat segmentasi mad'u sangat komplek jika ditinjau dari berbagai sisi. Untuk menghalau laju kehidupan modern tersebut maka diperlukan strategi dakwah kontemporer dalam menghadapi pola hidup modern.

\section{METODE PENELITIAN}

Metode penelitian ini adalah penelitian kepustakaan (libraryresearch). Penelitian kepustakaan dilakukan dengan mengumpulkan berbagai sumber data relevan yang berasal dari sumber bacaan primer dan sekunder dari suatu topik permasalahan. Pada penelitian ini topik permasalahan strategi media dakwah kontemporer.

\section{PEMBAHASAN}

Istilah strategi dapat berarti "ilmu tentang perencanaan dan pengarahan operasi militer secara besar-besaran". Selain itu dikenal pula dengan "kemampuan yang terampil dalam menangani dan merencanakan sesuatu". Perlunya taktik dan strategi dalam usaha mencapai tujuan, termasuk menyebarluaskan informasi atau ajaran agama (dakwah), maka pemahaman tentang taktik dan strategi merupakan hal yang tidak boleh diabaikan.

Dakwah adalah proses menjadikan perilaku seorang untuk menjalankan Islam sebagai agama rahmatan lil alamin. Dakwah disampaikan kepada seluruh umat manusia dengan melibatkan unsur-unsur dai (subjek), maaddah (materi), thariqah (metode), washilah (media), dan mad'u (objek). Tujuan dakwah Islam yaitu mencapai kebahagiaan hidup di dunia dan akhirat. Maka dalam hal ini, dakwah dapat dipahami sebagai proses internalisasi, transformasi, transmisi, dan difusi ajaran Islam dalam kehidupan masyarakat. Dakwah juga mengandung arti panggilan dari Allah swt. dan Rasulullah saw. untuk umat manusia agar percaya kepada ajaran Islam dan mewujudkan ajaran yang dipercayainya itu dalam segala segi kehidupan. Sasaran dakwah adalah untuk menumbuhkan pengertian, kesadaran, penghayatan, dan pengenalan terhadap ajaran agama yang dibawa oleh para juru dakwah. Juga untuk mempertemukan kembali fitrah manusia dengan agama, atau menyadarkan manusia tentang perlunya bertauhid yang 
dimanifestasikan kedalam pengamalan ajaran Islam. Secara umum, dakwah bertujuan untuk memanggil manusia kembali pada syariat atau hukumhukum agama, supaya dapat mengatur dirinya sesuai dengan ketentuan agama. Di sini agama menurut bukan sekedar satu sistem kepercayaan saja, tetapi di dalamnya terdapat multisistem untuk mengatur kehidupan manusia, baik mengagatur hubungan secara vertikal (hablum min Allah) maupun horizontal (hablum min an-Nas). Dakwah yang dilakukan oleh para dai memiliki keutamaan-keutamaan, yaitu untuk mengangkat panji kebenaran dan mewujudkan kebaikan sehingga umat menjadi baik dan senantiasa melaksanakan kebaikan dan mencegah kemungkaran.

Sebuah pendekatan melahirkan sebuah strategi yaitu semua cara untuk mencapai tujuan yang ditetapkan. Setiap strategi menggunakan beberapa metode dan setiap metode membutuhkan teknik, yaitu cara yang lebih spesifik dan lebih operasional. Selanjutnya setiap teknik membutuhkan taktik, yaitu cara yang lebih spesifik lagi dari teknik. Strategi tersebut memerlukan metode, teknik, cara dan taktik yang diperlukan secara bersamaan. Dakwah dapat berjalan dengan baik dan efektif, apabila tugastugas dakwah dilaksanakan sesuai dengan rencana dan ketentuan-ketentuan yang telah ditetapkan oleh penentu kebijakan. Selanjutnya tugas dakwah tersebut diiplementasikan dalam sebuah rencana yang tepat dan berkesinambungan. Kegiatan dakwah perlu menggunakan strategi yang mampu merespon segala aspek kehidupan manusia, sekaligus dituntut untuk mampu mengatasi dan menetralisir gejolak sosial yang lahir. Itulah sebabnya strategi merupakan perpaduan dari perencanaan (planning) dan managemen dakwah untuk mencapai suatu tujuan. Islam sangat dikenal sebagai agama dakwah, bisa juga disebut sebagai agama yang memiliki misi khusus yaitu agama yang harus disebarkan kepada umat manusia secara keseluruhan.

Istilah kontemporer adalah istilah yang terkait dengan masa dan masa yang dimaksud adalah masa sekarang atau era modern di dalamnya ditemukan alat-alat komunikasi yang serba canggih dan baru. Sementara Istilah dakwah kontemporer adalah gabungan dari tiga suku kata yaitu strategi, dakwah dan kontemporer. Penggabungan ini melahirkan satu makna tersendiri yaitu adanya satu system atau teknik dakwah di era teknologi modern. Dengan demikian dapat dipahami bahwa strategi dakwah kontemporer dimaksudkan adalah sebuah strategi dalam melancarkan dakwah di era modern dalam menghadapi kehidupan yang menggunakan 
teknologi. Strategi dakwah kontemporer dalam menghadapi pola hidup modern Terdapat tiga indikator adanya dakwah kontemporer yaitu pertama, dai kontemporer. Kedua Dakwah dengan menerapkan materi dakwah yang kontemporer. Ketiga, kegiatan dakwah dengan menggunakan media teknologi kontemporer. Sedangkan pola hidup modern oleh penulis mengambil empat pola hidup yaitu hiburan, makanan, pakaian dan kepercayaan.

Pesan dakwah harus dikemas semenarik mungkin agar memiliki daya tarik sehingga dapat diterima dengan baik oleh mad" u. Pesan dakwah harus dikemas melalui konten-konten yang akrab dengan generasi kekinian. Penggunaan portal dakwah dengan konten tidak selalu berupa tulisan, namun juga dapat dikemas dalam bentuk vlog, soundcloud, infografis, dan juga meme, dimuat di YouTube agar dakwah makin meluas. Dakwah juga dapat dilakukan secara online dengan memanfaatkan YouTube, Instagram, dan sebagainya, sebelum akhirnya bisa fenomenal secara offline. Kedua, pengemasan pesan-pesan dakwah harus menarik. Sebab, sebaik apapun materi dakwah tanpa didukung dengan kemasan yang menarik terkadang ditinggalkan orang. Dengan dua pendekatan tersebut tantangan dakwah pada generasi milenal dapat dilalui dan diselesaikan dengan baik. Maka, agar pesan dapat diterima dengan baik oleh komunikan (penerima pesan), maka pesan komunikasi yang terdiri dari isi pesan dan lambang harus diproduksi dengan sangat hati-hati.

\section{KESIMPULAN}

Pendekatan dakwah kini tidak lagi cukup dengan cara-cara konvensional. Perkembangan teknologi yang kian cepat menuntut penyesuaian. Dakwah harus lebih optimal disampaikan lewat pendekatan Starategi Media Dakwah Kontemporer karena generasi milenial lebih cenderung menggunakan aplikasi-aplikasi yang sifatnya interaktif, seperti whatsap. Karena itu, dai disarankan untuk memanfaatkan sumber daya manusia dan teknologi komunikasi yang pertumbuhannya sangat cepat. Penggunaan media social harus dimanfaatkan semaksimal mungkin dalam rangka menjangkau mad'u yang lebih luas sehingga pesan dakwah terserap lebih banyak. 


\section{DAFTAR PUSTAKA}

Syed Muhammad Naquib Al-Attas.(2011).Islam and Sekularisme, Terjemah: Khalif Muammar, dkk. Bandung: PIMPIN, h. 165

Cindy Rizal Putri Paramitha. (2011). Analisis Faktor Pengaruh Promosi Berbasis Sosial Media Terbadap Keputusan Pembelian Pelanggal dalam Bidang Kuliner, Tesis, Fak. Ekonomi. UNDIP:Semarang, h. 17.

Onong Uchjana Effendy.(2003).Ilmu, Teori, dan Filsafat Komunikasi. Bandung: Citra Aditya Bakti, h. 5.

Deddy Mulyana. (2005). Ilmu Komunikasi Suatu Pengantar. Bandung: Remaja Rosdakarya. h. 20.

Widjaja. (2000). Ilmu Komunikasi Pengantar Studi. Jakarta: Rineka Cipta,h. 14 